\title{
Książki wydane przez pracowników i doktorantów zakładów językoznawczych Instytutu Filologii Polskiej UAM w Poznaniu w roku 2010
}

Zdzislawa Krąży ń s ka, Staropolskie konstrukcje z przyimkami. Część IV, „Biblioteczka Poznańskich Studiów Polonistycznych Serii Językoznawczej”, t. 40, Wydawnictwo „Poznańskie Studia Polonistyczne”, Poznań 2010, ss. 202.

Część czwarta monografii poświęconej staropolskim konstrukcjom z przyimkami zawiera charakterystykę konstrukcji z narzędnikiem i miejscownikiem (nad, pod, przed, za, miedzy łączą się z narzędnikiem; $o, p r z y, n a, w$ łączą się $\mathrm{z}$ miejscownikiem). Prawie wszystkie wymienione przyimki - oprócz $z$ oraz przy - występują też w związkach $\mathrm{z}$ biernikiem (przedstawiono je w części pierwszej i drugiej). Autorka podkreśla, że zasadnicza różnica między oboma typami konstrukcji (konstrukcje z biernikiem wobec konstrukcji z narzędnikiem i miejscownikiem) wynika $\mathrm{z}$ obecności w nich odmiennych przypadków: biernik wnosi do konstrukcji kategorialna cechę semantyczną ,ukierunkowanie", natomiast narzędnik i miejscownik cechę „lokalizacja”.

Opis konstrukcji przebiega wedle podobnego schematu, co w częściach po- przednich. Wypada podkreślić, że takie podejście ułatwia rozmaite porównania, dające podstawę do zarysowania syntezy, a taki jest główny zamysł podjętych dociekań. Autorka we wszystkich częściach konsekwentnie dowodzi, że prawie wszystkie relacje powstające $\mathrm{z}$ udziałem przyimków zanurzone są $\mathrm{w}$ podstawowym układzie przestrzennym, który podlega wielokierunkowym transformacjom. Skupienie się na procesach transformacyjnych, a ponadto poszukiwanie elementarnych cech wyznaczających kierunki transformacji stanowią centrum rozważań. Należy dodać, że ciagi transformacyjne ujawniają się dzięki systematycznemu oglądowi kontekstów, przebiegające$\mathrm{mu} \mathrm{z}$ zachowaniem tych samych reguł w odniesieniu do wszystkich wyrażeń przyimkowych. Nadrzędny jest podział oddzielający konstrukcje przestrzenne od nieprzestrzennych. Ponieważ jednak nie ma między nimi ostrej granicy, wskazuje się pas przejściowy, określony mianem konstrukcji quasi-przestrzennych, stanowiący przejście między konstrukcjami przestrzennymi a konstrukcjami transformowanymi z wykrystalizowanym mniej 
lub bardziej wyraziście kategorialnym znaczeniem (np. dla konstrukcji z przyimkiem $z$ w połączeniu $\mathrm{z}$ narzędnikiem transformacji podlega cecha nieprzestrzenna „coś razem z czymś innym”, stanowiąca podstawę dla transformowanych znaczeń, np. 1) równorzędność obiektów implikowana przez predykat, np. rozłqczyć lenistwo z nieszczęściem, 2) współuczestnictwo w akcji drugiej osobowej strony, np. rozdzielić oćczyznę z kim, 3) w wyrażeniu przyimkowym element towarzyszący akcji, np. iść na czyj dom $z$ ostra broniq). Zacieranie się kategorialnej semantyki to kolejne przekształcenie, jakiemu podlegają konstrukcje z wyrażeniami przyimkowymi. Odsemantyzowanie konstrukcji prowadzi $-\mathrm{z}$ jednej strony - do wyłaniania się konstrukcji typu dopełnieniowego, nazwanych $\mathrm{w}$ pracy quasi-przedmiotowymi (pytać, co by sie działo z synem), z drugiej - do powstawania nowych jednostek leksykalnych współfunkcyjnych z przysłówkami (na krótce 'krótko, zwięźle').

Oczekujemy $\mathrm{z}$ zainteresowaniem podsumowania badań (część piąta), które - wedle informacji autorki - jest gotowe do druku.

Agnieszka K u la, Cechy stylowe publicystyki ekonomicznej na materiale „Polityki" z lat 1957-2004, Wydawnictwo Poznańskie, Poznań 2010, ss. 326.

Książka sytuuje się w nurcie badań nad przekazami medialnymi, a jej celem jest nakreślenie - przy użyciu narzędzi stylistycznych i pragmalingwistycznych - prymarnych cech stylowych, decydujących o kształcie badanych tekstów. Teoria cech stylowych pozwala na funkcjonalne, a nie strukturalne, hierarchiczne podejście do analiz tekstowych, a także na rozpoznanie wszystkich istotnych elementów sytuacji komunikacyjnej i ich wpływu na konfigurację cech stylowych - tym samym wybrane narzędzia okazują się przydatne i skuteczne w analizach medioznawczych.

Do badań materiałowych posłużyły teksty z tygodnia „Polityka”, losowo wybrane z każdego miesiąca lat 1957-2004. Uzyskano w ten sposób korpus 645 tekstów publicystycznych. Wskazany przedział czasowy umożliwia zarówno analizę zjawisk w najnowszej publicystyce, jak i porównanie sposobów przedstawiania problematyki ekonomicznej w państwie niedemokratycznym oraz $\mathrm{w}$ demokracji, a tym samym pozwala na analize zmian stylu. Oglądowi poddano teksty, które redakcja tygodnika uznała za artykuły o tematyce gospodarczej i umieściła w dziale „Gospodarka" (nowa formuła pisma od 1994 roku) lub które oznaczyła jako teksty publicystyki ekonomicznej w dołączonym do rocznika spisie treści. Ponadto od momentu, w którym raporty zostaja wyodrębnione $\mathrm{z}$ działów tematycznych, dołącza się je do badanego materiału na podstawie analiz słownikowych pojęcia „gospodarka".

W książce można wskazać dwie zasadnicze części. Pierwsza poświęcona jest oglądowi kwestii teoretycznych, skupionych wokół teorii cech stylowych (rozdział pierwszy) oraz wokół zagadnienia kontekstu (rozdział drugi). Rozdział pierwszy traktuje o zjawiskach związanych $\mathrm{z}$ rozumieniem stylu, wyboru stylistycznego, cechy stylowej. Przedstawia różne sposoby hierarchizacji cech stylowych, wyznaczników tych cech oraz związku teorii cech stylowych z kategorią stosowności i zagadnieniem dobrego stylu. Autorka zwraca uwagę na problem obiektywności cechy stylowej oraz na łańcuchowy charakter teorii cech stylowych. W rozdziale drugim odnaleźć można omówienie roli czynników poza- 
językowych, charakterystykę kontekstu, naświetlenie roli nadawcy i odbiorcy w systemie gospodarki centralnie zarządzanej oraz wolnorynkowej.

W drugiej części książki wcześniej opisane narzędzia stylistyczne oraz pragmalingwistyczne użyte zostały w przeprowadzonych analizach materiałowych, zebranych w czterech grupach ze względu na konfiguracje powtarzających się i charakterystycznych dla danych tekstów cech stylowych. Warto zauważyć, że wyodrębnione typy tekstów publicystyki ekonomicznej (o gospodarce specjalistycznie, ideologicznie, krytycznie oraz raport o gospodarce) nie funkcjonują w izolacji. Z przedstawionych badań wynikają wnioski świadczące o ewolucji stylistycznej artykułów, o wycofywaniu się niektórych cech stylowych z pozycji dominanty, a pojawianiu się innych. $\mathrm{Z}$ tego względu ważna staje się analiza zależności łańcuchowych (powiązań między zasadami, cechami i wykładnikami stylowymi). W ostatnim rozdziale analizę cech stylowych w poszczególnych grupach dopełnia omówienie architektonicznych, tektonicznych i graficznych wykładników stylu.

Tomasz Lis owski, Sola Scriptura. Leksyka Nowego Testamentu Bibliigdańskiej (1632) na tle porównawczym. Ujęcie kwantytatywno-dystrybucyjne, Wydawnictwo Rys, Poznań 2010, ss. 534.

Przedmiotem rozprawy jest słownictwo Nowego Testamentu Biblii gdańskiej z 1632 roku - przekładu protestanckiego (stanowiącego dla polskich ewangelików jedyny aprobowany przez władze kościelne tekst Pisma Świętego aż do lat 60. XX wieku) autorstwa Daniela Mikołajewskiego. Przekład ten zamyka serię polskich renesansowych translacji biblijnych, zainicjonowana $\mathrm{w}$ połowie
XVI stulecia. Analizie poddane zostało słownictwo na tle trzech translacji wcześniejszych: Nowego Testamentu Biblii brzeskiej z 1563 roku (pierwszy drukowany innowierczy - kalwiński - przekład całej Biblii), Nowego Testamentu gdańskiego (w którego opracowaniu też uczestniczył Daniel Mikołajewski), wydanego w Gdańsku w 1606 roku, Nowego Testamentu Biblii w katolickim tłumaczeniu jezuity Jakuba Wujka (1599), z odwołaniami do wcześniejszego, wydanego w 1593 roku Nowego Testamentu w przekładzie Wujka. Wybór tła porównawczego uzasadniony jest następującymi względami: po pierwsze, Biblia gdańska pozostaje z wybranymi translacjami w relacjach intertekstowych, po drugie, Biblia gdańska, jak i trzy wcześniejsze przekłady, z którymi wchodzi w relacje filiacyjne, jest dokumentem istotnego etapu ewolucji polskiego języka literackiego, a zarazem istotnego etapu kształtowania się jego odmiany funkcjonalnejpolskiego stylu biblijnego.

Celem analizy jest charakterystyka kwantytatywno-dystrybucyjna zasobu leksykalnego Nowego Testamentu Biblii gdańskiej (1632) w odniesieniu porównawczym do tych wcześniejszych translacji, a także do czeskiego Nowego Testamentu Biblii kralickiej (1579-1593). Analiza prowadzona jest $\mathrm{z}$ założeniem, że obydwie perspektywy interpretacyjne podejmowanej problematyki - kwantytatywna i dystrybucyjna - są wobec siebie komplementarne, choć w przypadku konkretnych zagadnień jedna $\mathrm{z}$ nich może dominować nad drugą.

Dane natury kwantytatywnej pochodzą z opracowanych przez autora na potrzeby tej analizy pełnych list frekwencyjnych słownictwa wszystkich czterech uwzględnionych przekładów (ze względu na objętość publikowanych jednak frag- 
mentarycznie). Punktem odniesienia dla analizy dystrybucyjnej jest oryginalny grecki tekst Nowego Testamentu.

Charakterystyce kwantytatywno-dystrybucyjnej służą takie narzędzia analityczne jak: wielkość leksykonu i tekstu poszczególnych przekładów, dyspersja haseł leksykonu ze względu na ich frekwencję tekstowa, współczynnik obfitości słownictwa, przeciętna częstość haseł, parametr oryginalności słownictwa, udział poszczególnych autosemantycznych części mowy w leksykonie i tekście, stopień swoistości zasobu leksykalnego w wymiarze kwantytatywnym, dystrybucja leksyki charakterystycznej dla Nowego Testamentu Biblii gdańskiej i jednego lub dwu spośród trzech zestawianych z nim przekładów oraz leksyki swoistej poszczególnych translacji, wreszcie charakterystyka ich leksyki pod względem jej powszechności w polszczyźnie XVI wieku (miernikiem są w tym względzie dane statystyczne Stownika polszczyzny $X V I$ wieku), pozwalającej na rekonstrukcję przeciętnej kompetencji leksykalnej ówczesnego użytkownika polszczyzny (pisanej).

Tak przeprowadzona analiza kwantytatywno-dystrybucyjna pozwala na sformułowanie następujących wniosków:

1. Pod względem kwantytatywnym za sprawą liczby autosemantycznych haseł oraz liczby ich użyć tekstowych Nowy Testament Biblii gdańskiej zbliża się do Nowego Testamentu Biblii brzeskiej, podczas gdy Nowy Testament gdański, redagowany także przez Daniela Mikołajewskiego, upodabnia się do przekładu Jakuba Wujka.

2. Pod względem dystrybucyjnym Nowy Testament Biblii gdańskiej wykazuje większe podobieństwo leksykalne do przekładu Wujkowego niż do $B i$ blii brzeskiej (której z założenia winien być rewizja). Dowodzą tego identyczne wybory leksykalne w miejscach paralelnych, leksyka charakterystyczna, powinowactwa leksykalne między Bibliq gdańska, Nowym Testamentem gdańskim i przekładem Wujka. Daniel Mikołajewski, protestancki duchowny, mimo różnic doktrynalnych częściej w poszukiwaniu adekwatnego polskiego ekwiwalentu greckiego leksemu sięgał do wzorców translacyjnych zawartych w katolickiej Biblii Jakuba Wujka aniżeli do rozwiązań kalwińskiej Biblii brzeskiej. Świadczy to o istnieniu niezależnej od względów konfesyjnych polskiej biblijnej tradycji translatorskiej.

3. Odwołując się do Biblii kralickiej, Daniel Mikołajewski podtrzymał zrodzoną jeszcze $\mathrm{w}$ średniowieczu tradycję wykorzystywania biblijnych przekładów czeskich jako tekstów pomocniczych w pracy translacyjnej.

4. Prawdopodobnie ewangelicy polscy w początku XVII wieku dysponowali już większą niż przeciętna kompetencją językowa, przynajmniej w zakresie percepcji przekazu biblijnego. Mogło to już bowiem być trzecie pokolenie chrześcijan odrzucających nauki Kościoła rzymskiego, przywykłych do samodzielnej lektury Biblii.

5. Daniel Mikołajewski jawi się jako tłumacz-filolog rozważnie poszukujący najbardziej adekwatnych polskich ekwiwalentów leksyki oryginału. Wiedziony protestancką doktrynalną zasadą sola Scriptura, która jest kwintesencją przekonania, że to sam Bóg przemawia do człowieka każdym słowem Pisma Świętego, odwołuje się wzorem swoich poprzedników do przekładu czeskiego, nie waha się sięgać po przekłady doktrynalnie obce, o ile mogá one dostarczyć najtrafniejszych w danym kontekście podstawień leksykalnych. 
Miasto w perspektywie onomastyki i historii, pod redakcją Ireny Sarnowskiej-Giefing i Magdaleny Graf, Wydawnictwo Poznańskiego Towarzystwa Przyjaciół Nauk, Poznań 2010, ss. 630.

Tom zawiera 45 tekstów wygłoszonych podczas konferencji naukowej „Miasto w perspektywie onomastyki i historii”, która odbyła się w Poznaniu 5-7 stycznia 2009 roku. Intencją organizatorów konferencji było zintegrowanie przedstawicieli różnych dyscyplin humanistycznych, podejmujących w swych badaniach zagadnienia związane $\mathrm{z}$ przestrzenią miejska. W wyznaczonym zakresie tematycznym znalazły się takie zagadnienia jak: kształtowanie się nazwiska mieszczańskiego w Polsce i Europie, antroponomastykony wybranych miast, dynamika przemian nazewniczych związanych z dziejami miasta, regionu, kraju, nazewnictwo miejskie, doświadczenie historyczne jako niezbędny kontekst dla badań onimii miejskiej oraz miasto z perspektywy dokumentów archiwalnych (ewaluacja źródeł pod kątem badań nad onimia). Szeroki zakres tematyczny zaowocował podziałem zebranych artykułów na sześć działów problemowych: metodologia badań nazewniczych (3 artykuły), antroponimia (17), urbonimia i urbanonimia (12), onomastyka literacka i kulturowa (7), miasto z perspektywy onomastyki, historii i archiwistyki (3), przydatność materiałów archiwalnych do badań onomastycznych (3). Autorami artykułów zebranych $\mathrm{w}$ tomie są m.in. Kwiryna Handke, Aleksandra Cieślikowa, Zygmunt Zagórski, Karol Zierhoffer, Rudolf Šrámek, Fridhelm Debus, Tomasz Jurek, Jacek Wiesiołowski.

Perspektywy wspótczesnej frazeologii polskiej. Teoria. Zagadnienia ogólne, pod redakcją Stanisława Bąby, Krzysztofa Skibskiego, Michala

Szczyszka, Wydawnictwo Naukowe UAM, Poznań 2010, ss. 193.

Książka stanowi pokłosie Pierwszego Ogólnopolskiego Sympozjum „Perspektywy współczesnej frazeologii polskiej”, które odbyło się w Poznaniu 27 października 2008 roku. Ideą tego spotkania naukowego było zaprezentowanie aktualnych kwestii metodologicznych polskiej frazeologii oraz wyznaczenie perspektyw badawczych. Organizatorzy zwrócili się z prośbą o uczestnictwo do wybitnych polskich specjalistów ze znamienitych ośrodków akademickich, ponieważ pragnęli dzięki tej okazji przybliżyć studentom (nie tylko studiów filologicznych) problematykę wskazanej dziedziny językoznawstwa oraz zachęcić przyszłych seminarzystów i badaczy do indywidualnej aktywności. Sympozjum zostało pomyślane jako jednodniowa prezentacja referatów połączona $\mathrm{z}$ dyskusją $\mathrm{z}$ udziałem studentów. Obecność tych ostatnich była kluczowa, ponieważ spotkanie miało przede wszystkim cele dydaktyczne. Potwierdzeniem tego jest wydanie książki z przedstawionymi referatami, która staje się kompendium wiedzy dotyczącej podstaw metodologicznych współczesnej frazeologii.

Efektem sympozjum jest zbiór znakomitych tekstów nadesłanych redaktorom przez wybitnych badaczy - uczestników konferencji:

1. Wojciech Chlebda, Skrzydlate słowa a frazeologia.

2. Gabriela Dziamska-Lenart, 110 lat polskiej frazeografii.

3. Piotr Fliciński, Sposoby pomnażania wspótczesnego zasobu frazeologicznego polszczyzny.

4. Jolanta Ignatowicz-Skowrońska, Frazeologizmy we współczesnej prozie polskiej. 
5. Iwona Kosek, Fleksja i sktadnia zwiazków frazeologicznych - stan badań, problemy opisu i perspektywy.

6. Stanisław Koziara, Biblizmy frazeologiczne $w$ zasobach współczesnej polszczyzny.

7. Jarosław Liberek, Zmiany w zasobie frazeologicznym współczesnej polszczyzny.

8. Alicja Nowakowska, Porównania frazeologiczne (zarys problematyki).

9. Anna Pajdzińska, Przydatność frazeologizmów w badaniu językowego obrazu świata.

10. Magdalena Puda-Blokesz, Frazeologizmy pochodzenia mitologicznego w języku polskim (zasób, stan i perspektywy opisu).

Przygotowany w ten sposób podręcznik ma podstawową akademicką zaletę jest $\mathrm{z}$ racji wielu autorów dyskursywny, tj. istotnie wpisuje się jako głos krytyczny w ciągłość polskiej refleksji frazeologicznej. Autorzy, przywołując teksty klasyczne, konstruują perspektywę badawczą frazeologii, nawiązując do nowych wyzwań metodologicznych. Taka formuła podręcznika zdecydowanie uatrakcyjnia przekaz niezbędnych informacji, ale, co ważniejsze, inspiruje do badań własnych.

Redaktorzy książki są przekonani, że ta publikacja zyska liczne grono odbiorców w środowisku naukowym polskiej humanistyki: nie tylko wśród badaczy i studentów filologii, co gwarantuje kulturowa swoistość frazeologii, ale - właśnie ze względu na specyfikę dziedziny - także wśród badaczy i studentów kulturoznawstwa, antropologii kulturowej, socjologii, psychologii, historii, przedstawicieli nauk o człowieku i o jego historii, o jego możliwościach poznawczych, o jego funkcjonowaniu w otaczającym świecie.

Ponieważ wspomniane sympozjum zostało zaplanowane jako cykliczne, to omawiana książka pokonferencyjna może stać się pierwszą w serii wydawniczej zatytułowanej „Frazeologia polska”. Każda następna publikacja $\mathrm{w}$ tej serii pomyślana jako kompendium, skrypt, podręcznik dla wskazanego powyżej grona odbiorców przedstawiałaby odrębne zagadnienie dotyczące problematyki frazeologicznej. W Wydawnictwie Naukowym UAM złożone zostały materiały z kolejnej edycji sympozjum - w 2012 roku ukaże się drugi tom Perspektyw... poświęcony wariantywności we frazeologii.

Przemyslaw Wiatrowski, Morfologiczne i leksykalne wyktadniki negatywnych emocji w „Przewodniku Katolickim" z lat 1895-2005, Wydawnictwo Rys, Poznań 2010, ss. 367.

W książce przedmiotem opisu są wypowiedzi opublikowane w latach 1895 -2005 na łamach „Przewodnika Katolickiego" - jednego z najdłużej ukazujących się polskich periodyków oraz najstarszego tygodnika katolickiego, który w bardzo dużym stopniu zachował ciągłość swych tradycji. Praca ma charakter empiryczny, materiałowo-interpretacyjny. Jej celem jest analiza wynotowanych z kart czasopisma faktów językowych służących do uzewnętrzniania negatywnych emocji. Obserwacją objęto morfologiczne oraz leksykalne ich wskaźniki (ekspresywizmy fleksyjne, ekspresywizmy słowotwórcze, ekspresywizmy leksykalne oraz leksykalne nazwy emocji). W oglądzie jakościowym tych jednostek wykorzystano podstawowe narzędzia badawcze wypracowane na gruncie semantyki strukturalnej (analizę semową oraz koncepcję pola znaczeniowego).

Dysertacja składa się z dwóch zasadniczych części, poprzedzonych zaprezentowaniem podstawowych założeń badawczych oraz uwagami na temat dziejów „Przewodnika Katolickiego”. Pierwsza 
część pracy jest wprowadzeniem w złożoną problematykę wiążącą się z emocjami. Podstawowe zagadnienia ujmuje się tu z dwóch uzupełniających się perspektyw - psychologicznej i językoznawczej. Przedstawiono najważniejsze ustalenia psychologów na temat emocji, pojawiające się w literaturze psychologicznej terminy i definicje zjawisk emocjonalnych, niektóre propozycje stratyfikacyjne emocji oraz najistotniejsze ich cechy i funkcje. Zaprezentowano ponadto teoretyczno-metodologiczne podstawy badania języka emocji. Ten fragment opracowania zawiera wykładnię kluczowych dla prowadzonych analiz pojęć, przegląd najważniejszych typologii emocji oraz sposobów ich manifestowania, a także omówienie literatury przedmiotu.

Część druga studium ma charakter empiryczny. Jej przedmiotem jest wyekscerpowany z kart „Przewodnika Katolickiego" zbiór środków językowych sygnalizujących negatywne emocje nadawców czasopisma. Kolejne rozdziały tej części zawierają analizę zabiegów morfologicznych (przybierających postać ekspresywizmów fleksyjnych oraz słowotwórczych) oraz faktów leksykalnych. Badaniami objęto słownictwo nazywające emocje (afekty i postawy emocjonalne) oraz rzeczownikowe leksemy opisowo-ekspresywne. Analizy dopełniają uwagi odnoszące się do wyrazowych wykładników natężenia emocji oraz formalno-semantyczna charakterystyka słownictwa denotującego emocje. Końcowy fragment opracowania jest podsumowaniem wyników badań, a także próbą określenia głównych funkcji sygnalizatorów emocji oraz spojrzenia na zaobserwowane elementy językowe z perspektywy diachronicznej.

Rozprawę zamykają: objaśnienia stosowanych skrótów oraz wykaz literatury przedmiotu.
Żywe problemy historii jezyka, pod redakcją Marcina Kuźmickiego i Marka Osiewicza, Wydawnictwo Poznańskiego Towarzystwa Przyjaciół Nauk, Poznań 2010, ss. 219.

Książka jest drugą z kolei publikacją, która powstaje z inspiracji badaczy poznańskiego (Zakład Historii Języka Polskiego Uniwersytetu im. A. Mickiewicza) oraz zielonogórskiego (Zakład Historii i Pragmatyki Języka Polskiego Uniwersytetu Zielonogórskiego) środowiska naukowego oraz naukowców z innych ośrodków badawczych zaproszonych do dyskusji nad zagadnieniami dotyczącymi najdawniejszych dziejów polszczyzny. Pierwsza dotyczyła zagadnień sytuujących się na styku grafii i fonetyki (Dokument pisany $w$ badaniach historyka języka polskiego, Zielona Góra 2010). Druga, niniejsza książka, poświęcona jest w części pierwszej zagadnieniom związanym ze słowotwórstwem, drugą część stanowi natomiast zbiór tekstów, który umownie zatytułowany został „Przekraczanie granic (w przestrzeni i czasie)", gdyż pojęcie klucz stanowi wieloznacznie konceptualizowane słowo granica.

Część pierwsza zawiera artykuły, które poruszają problemy związane z tworzeniem modeli opisu procesów słowotwórczych (np. A. Janowska, M. Pastuchowa, Między leksykologia a stowotwórstwem. Osiagnięcia $i$ propozycje katowickiej szkoty stowotwórstwa historycznego; E. Kwapień, Słowotwórstwo rzeczowników polskich $w$ XIX wieku typy struktur $i$ kierunki ich rozwoju), zawiera także teksty, które poruszają zagadnienia bardziej szczegółowe, odnoszące się do interpretacji konkretnych procesów słowotwórczych (np. R. Zarębski, Stowotwórcza interpretacja derywatów $z$ prefiksami obcego pochodzenia $w$ dziejach języka polskiego; A. Rejter, Uniwer- 
bizacja jako problem historycznojęzyko$w y)$. W części drugiej owa „granica” jest naznaczonym miejscem, które ukazuje problem podziału w rozważaniach historycznojęzykowych. Podziału, który jest rozpatrywany $\mathrm{w}$ aspekcie terytorialnym (np. M. Cybulski, Podziaty społeczne $i$ terytorialne odzwierciedlone $w$ formutach dawnej polskiej etykiety językowej), jak również pojęciowym (M. Hawrysz,
Terminologia jako wyznacznik granic wspólnoty religijnej).

Zgromadzone $\mathrm{w}$ obu tomach prace są najlepszym dowodem na to, że istnieje pilna potrzeba wypracowania nowego modelu opisu dla historii języka polskiego.

Sporządziła Agnieszka Krygier-Łaczkowska 